\title{
A virtual learning environment for a remedial differential calculus course
}

\section{Un ambiente virtual de aprendizaje para un curso remedial de cálculo diferencial}

\author{
AGUILAR-SALINAS, Wendolyn Elizabeth†* \& DE LAS FUENTES-LARA, Maximiliano \\ Universidad Autónoma de Baja California, Faculty of Engineering, Mexico. \\ ID $1^{\text {st }}$ Author: Wendolyn Elizabeth, Aguilar-Salinas / ORC ID: 0000-0003-2223-9234 / CVU CONACYT ID: 265060 \\ ID $1^{\text {st }}$ Co-author: Maximiliano, De Las Fuentes-Lara / ORC ID: 0000-0002-1001-4663 / CVU CONACYT ID: 412049
}

DOI: $10.35429 / J M Q M .2021 .8 .5 .1 .9$

Received January 10, 2021; Accepted June 30, 2021

\begin{abstract}
Information and communication technologies have led to the development of new learning modalities and techniques. This research is based on the design of a remedial course for the subject of Differential Calculus and its corresponding method of evaluation in a virtual learning environment, which allows the student practical and autonomous learning. Its elaboration consists of two parts: the instructional design associated with the learning topics identified as necessary for the learning of the Differential Calculus and the evaluation method for the achievement of the learnings. This course is expected to assist the student in the possible learning lags of the Differential Calculus to successfully complete the Integral Calculus learning unit.
\end{abstract}

VLE, Differential Calculus, Instructional Design, Evaluation Methods

\begin{abstract}
Resumen
Las tecnologías de información y comunicación han propiciado el desarrollo de nuevas modalidades y técnicas de aprendizaje. Esta investigación se basa en el diseño de un curso remedial para la materia de Cálculo Diferencial y su correspondiente método de evaluación en un ambiente virtual de aprendizaje, que le permite al estudiante un aprendizaje práctico y autónomo. Su elaboración consiste de dos partes: el diseño instruccional asociado a los tópicos de aprendizaje identificados como necesarios para el aprendizaje del Cálculo Diferencial y el método de evaluación para el logro de los aprendizajes. Se espera que este curso ayude al estudiante en los posibles rezagos de aprendizaje del Cálculo Diferencial para culminar con éxito la unidad de aprendizaje de Cálculo Integral.
\end{abstract}

AVA, Cálculo Diferencial, Diseño Instruccional, Métodos de evaluación

Citation: AGUILAR-SALINAS, Wendolyn Elizabeth \& DE LAS FUENTES-LARA, Maximiliano. A virtual learning environment for a remedial differential calculus course. Journal-Mathematical and Quantitative Methods. 2021. 5-8:1-9.

\footnotetext{
* Author Correspondence (E-mail: aguilar.wendolyn@uabc.edu.mx)

$\dagger$ Researcher contributing as first author.
} 


\section{Introduction}

The academic performance of students entering engineering careers is low, which makes it difficult to learn Differential Calculus (CD) and results in failure of the subject and school dropout (López, 2005). In some institutions in the country, the failure rate for CD is $80 \%$ and approximately $40 \%$ are forced to leave their studies due to failure for the third time (Riego, 2013; Pineda, 2008).

The learning unit (UA) of CD is located in the common core of engineering sciences, within the basic stage at the Autonomous University of Baja California (UABC). This provides the bases or principles of topics such as inequalities, functions, limits, derivation and optimization, by developing in the student the skills, tools, knowledge, aptitudes, attitudes and values for the effective application of mathematics in engineering. Its objective is to provide students with knowledge that allows them to interpret, pose and solve engineering problems (Zúñiga, 2007), since the training of engineers demands mathematical learning that contributes to solving specific problems of a technological nature, but above all practical (Ruiz, Carmona and Montiel, 2016).

With the social distancing caused by COVID19, basic, middle and higher education institutions in Mexico have had to migrate to a new learning modality: online or virtual. The advantages of this modality can be summarized in five different areas: flexibility in the distribution of topics, variability in the times of each objective, flexibility in study time, greater interest in learning and the opportunity to interact and explore the topics through the use of simulators (Vasquez, 2020).

Within the UABC, the Center for Open and Distance Education (CEAD) is the body responsible for providing institutional administration services for online courses, either in the blended or distance mode, which began in the 2012 semester. 2 and included activities associated with teacher training, instructional design (DI) and evaluation methods (Avitia, Candolfi, Arellano \& Uriarte, 2014). Within these activities the development of ID deals with: the planning, preparation and design of the resources and environments necessary for learning to take place (Bruner, 1969).
The instructional designer (teacher), in this case, will have to transcend the merely communicative aspects of the process to attend to the coherence and relevance of the contents, the objectives and the learning activities, which arise as an alternative to the questionnaires and make evident the concern to make the participation of students more active in the learning process (Chiappe, 2008), by having a broader, flexible and focused vision on the generation of general spaces and not on the development of specific strategies (Umaña, 2009).

The first instructional designs developed for the Mexicali School of Engineering (FIM) were completed in the 2016-1 school year and began to be used in the 2016-2 school year for semi-presential UAs. The Differential Calculus UA was not alien to this process, being implemented in a blended way. In the course of the 2016-2 to 2019-2 school cycles for this UA, no significant differences were found in the students' evaluations according to the learning modality.

Assuming that the effectiveness of an educational process is not in the modality in which it is taught, but in the pedagogical approaches, and based on the fact that there are no significant differences between the results obtained in the teaching of classes in face-toface or online modality (García, 2017), a remedial course of the UA of CD was designed for the students of the Faculty of Engineering Mexicali (FIM) of the UABC during the period 2021-1 through a virtual learning environment (AVA) with the Blackboard learning management system.

The remedial course of Functions and Derivatives will provide the student with the knowledge, methods and techniques, by favoring in the student critical reasoning, creativity, teamwork and interest in searching for information and solving problems.

\section{Objective}

Design a remedial course for the matter of Differential Calculus called Functions and Derivatives in the online mode, in accordance with the guidelines of the UABC educational model, as well as the corresponding academic model. 


\section{Theoretical framework}

VLEs are educational practices that operate, develop and take place on the Internet, and that allow communication between users (Coll and Monereo, 2008) in an effective and constant way, obeying the pedagogical principles that guide the development of the themes established for the learning (Dillenbourg, Schneider and Synteta, 2002), creating new spaces for collaboration between teachers and students, overcoming the traditional paradigms of teaching, impacting on the achievement of learning (Brioli and Garcial, 2011; Betegón, et al., 2012 ; Osuna and Abarca, 2013).

Therefore, López, Ledesma and Escalera (2009, p. 6) mention that: "A Virtual Learning Environment is the set of synchronous and asynchronous interaction environments, where, based on a curricular program, the teaching-learning process, through a learning management system".

For the construction of this VPA, the use of a DI was necessary, as a systemic, planned and structured process that must be carried out to produce courses in the face-toface or virtual modality, it is based on learning theories and goes from the definition from what the teacher wants the student to learn until the formative evaluation of the process (Agudelo, 2009). If ID is based on a constructivist approach, the teacher or learning designer is required to produce programs and materials of a much more facilitating than prescriptive nature (Guàrdia and Sangrà, 2005). In the same way, a change of pedagogical vision is required, which includes a change of roles and functions, to transcend the traditional model of instructional design, for another that demands greater flexibility and openness in the student's learning processes (Umaña, 2009).

Therefore, constructivist theories seem more appropriate for new educational contexts and offer more opportunities to design training actions that allow the achievement of professional skills, since as the learner is capable of interpreting multiple realities, he is better prepared to face situations of the real life. If a student can solve problems, he will be better prepared to apply his knowledge to new and changing situations (Guàrdia and Sangrà, 2005).
The models of constructivist instructional designs in distance education require technological supports, since they provide a series of tools that allow the student to become an active participant in the learning process, thus transcending the use of materials printed, to incorporate other types of media that are required for learning processes (Umaña, 2009).

\section{Methodology}

For the development of the VLE, it was necessary to develop a DI that will guide the sequence of learning activities, as well as evaluation methods to identify learning achievements.

\section{Instructional design}

The ID used is based on constructivist theories, so it tends for the designer to discover the best combination of materials and activities that guide the student to realize the value of their cognitive construct for future learning. This DI has four stages of a flexible system in which the stages are not sequential, but in a certain way simultaneous and influence each other, in which it is found: analysis, design, production, implementation and continuous review (Córica, Portalupi, Hernández and Bruno, 2010).

The first activity developed within the development of the DI was the general description of the course (Table 1), in this the generalities of the course are established, such as: name, password, academic level, validity of the study plan, academic programs in the that is taught, school year, credits, formative stage, nature of the subject and modality. As well as, the answer to the following questions, which will describe the development of the course in the blended mode: What will the student learn during the course? Understanding both the general competence and the general purpose of the course, how will the student learn? In which the general learning strategy is explained, how will you know she learned it? For this, the criteria, the general strategy of the course and the performance evidence were established. 


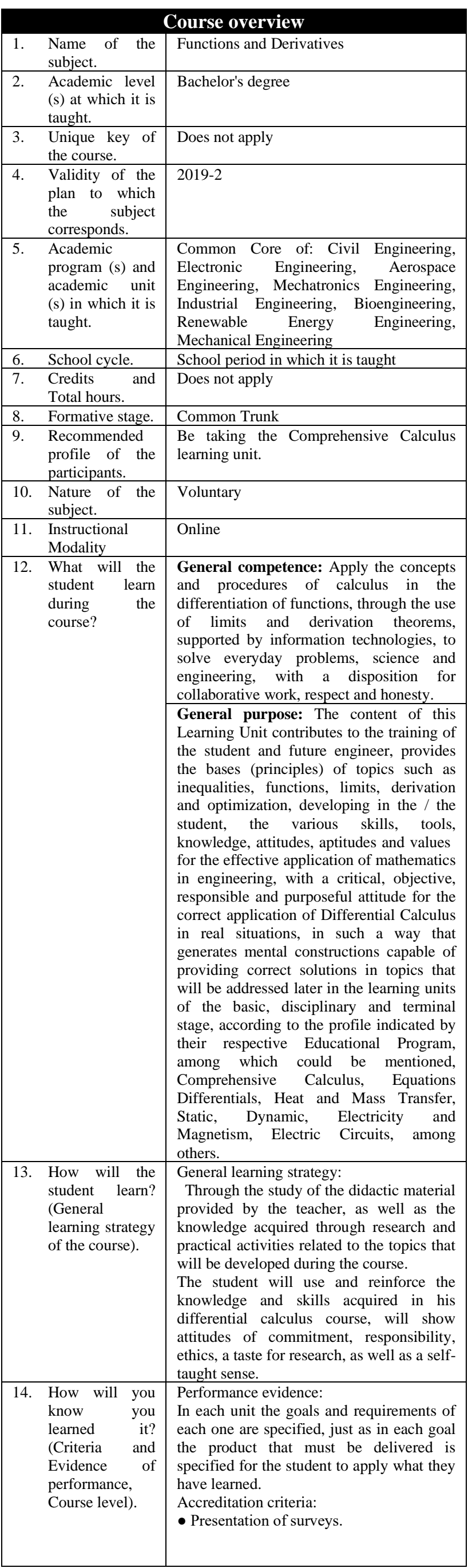

\begin{tabular}{|c|c|c|}
\hline & $\begin{array}{l}\text { Name and value } \\
\text { of the Learning } \\
\text { Units } \\
\text { incorporated } \\
\text { into the course. }\end{array}$ & $\begin{array}{l}\text { Each of the goals contains specific criteria } \\
\text { against which the student will be evaluated. } \\
\text { Each goal / practice has a percentage value } \\
\text { in the overall grade. } \\
\text { Evaluation: } \\
\text { Unit } 1 \text {. Functions of a variable. } \\
\text { - } 1 \text { week } 25 \% \text {. } \\
\text { Unit } 2 \text {. Limits and continuity. } \\
\text { - } 1 \text { week } 25 \% \text {. } \\
\text { Unit } 3 \text {. The derivative. } \\
\text { - } 1 \text { week } 25 \% \text {. } \\
\text { Unit } 4 \text {. Application of the derivative. } \\
\text { - } 1 \text { week } 25 \% \text {. }\end{array}$ \\
\hline 16. & $\begin{array}{l}\text { Support } \\
\text { materials: } \\
\text { readings, } \\
\text { exercises, } \\
\text { formats and } \\
\text { sites, by Unit. }\end{array}$ & $\begin{array}{l}\text { * MANUALS: } \\
\text { Own elaboration manual. } \\
\text { * BOOKS: } \\
\text { Boyce, W. and Diprima, R., (1994). } \\
\text { Calculus (First edition) Mexico. Ed. } \\
\text { CECSA. } \\
\text { Howard, A., (1991). Calculus and } \\
\text { Analytical Geometry (First edition). } \\
\text { Mexico. Ed. LIMUSA } \\
\text { Larson, R., Hostetler, R. and Edwards, B., } \\
\text { (1995). Calculus and Analytical Geometry } \\
\text { (Fifth edition). Spain. Ed. Mc Graw Hill. } \\
\text { Leithold, L., (1992). Mathematics prior to } \\
\text { calculus (Third edition). Mexico. Ed. } \\
\text { Oxford. } \\
\text { Leithold, L., (1992). The Calculus (Seventh } \\
\text { Edition). Mexico. Ed. Oxford. } \\
\text { López, I. and Wisniewski, P., (2006) } \\
\text { Differential Calculus of a variable with } \\
\text { applications (First edition). Mexico. Ed. } \\
\text { Thomson. } \\
\text { Purcell, E., Varberg, D. and Rigdon, S., } \\
\text { (2001). Calculus (Eighth Edition). Mexico. } \\
\text { Ed. Pearson Education. } \\
\text { Smith, R. and Minton, R., (2000). Calculus } \\
\text { Volume 1 (First edition). Colombia. Ed. } \\
\text { Mc Graw Hill. } \\
\text { Stewart, J., (2006). Calculus, Concepts and } \\
\text { Contexts (Third edition). Mexico. Ed. } \\
\text { Thomson. } \\
\text { Swokowski, E., (1989). Calculus with } \\
\text { Analytical Geometry (Second Edition). } \\
\text { Mexico. Ed. Grupo Editorial Iberoamérica. } \\
\text { Thomas, G. and Finney, R., (1998). I } \\
\text { calculate a variable (Ninth edition). } \\
\text { Mexico. Ed. Addison Wesley Longman. } \\
\text { Zabala, A., and Arnau, L., (2008). 11 Key } \\
\text { ideas, How to learn and teach skills? } \\
\text { Barcelona. Editorial Grao. Second edition. } \\
\text { *SOFTWARE } \\
\text { GEOGEBRA (www.geogebra.org/). }\end{array}$ \\
\hline 17. & $\begin{array}{l}\text { Course } \\
\text { enrollment, } \\
\text { operation and } \\
\text { evaluation } \\
\text { policies. }\end{array}$ & $\begin{array}{l}\text { I will be on time for face-to-face or chat } \\
\text { sessions. } \\
\text { I will have an appropriate and respectful } \\
\text { language when I communicate with my } \\
\text { classmates or teacher. } \\
\text { I will review weekly the material that the } \\
\text { teacher has uploaded to the platform. } \\
\text { I will make sure that my participation in } \\
\text { the activity, forum or evaluation has been } \\
\text { recorded. } \\
\text { Feedback will be made through the } \\
\text { medium that is being used (forum, } \\
\text { evaluation, activity). }\end{array}$ \\
\hline 18. & $\begin{array}{l}\text { Name and email } \\
\text { of the owner or } \\
\text { owners of the } \\
\text { course. }\end{array}$ & $\begin{array}{l}\text { Wendolyn Elizabeth Aguilar Salinas } \\
\text { aguilar.wendolyn@uabc.edu.mx } \\
\text { Maximiliano De Las Fuentes Lara } \\
\text { maximilianofuentes@uabc.edu.mx }\end{array}$ \\
\hline 19. & $\begin{array}{l}\text { Names, email, } \\
\text { municipality and } \\
\text { faculty of the } \\
\text { technical } \\
\text { support staff. }\end{array}$ & $\begin{array}{l}\text { Aglay González-Pacheco Saldaña } \\
\text { aglay@ uabc.edu.mx } \\
\text { Faculty of Engineering, Campus Mexicali. }\end{array}$ \\
\hline 20. & $\begin{array}{l}\text { Authors, dates } \\
\text { of elaboration } \\
\text { and last update. }\end{array}$ & $\begin{array}{l}\text { Preparation of the Instructional Design in } \\
\text { Online Mode (January-2021) } \\
\text { - D.C. Wendolyn Elizabeth Aguilar Salinas } \\
\text { - D.C. Maximiliano De Las Fuentes Lara }\end{array}$ \\
\hline
\end{tabular}

Table 1 Course overview Source: Self-made

AGUILAR-SALINAS, Wendolyn Elizabeth \& DE LAS FUENTES-LARA, Maximiliano. A virtual learning environment for a remedial differential calculus course. Journal-Mathematical and Ouantitative Methods. 2021 
Once these needs have been identified, educational goals are established, which will be achieved if the participants assimilate and put into practice the acquired knowledge (Gil, 2004; Gutiérrez, 1997), which must be aimed at the situations that students will have to face, making timely decisions that provide the best resources to achieve them (Escontrela, 2003). Corica et al. (2010) consider that it is essential for the learning process to have objectives to achieve, goals to meet, for which motivation and interest are essential.

Therefore, the second activity was the development of the goals, in which the goals to be achieved and the means to achieve them had to be clearly planned (Gil, 2004). Table 2 shows the construction of the goals of the first unit as an approach to the general map of the course, for which 15 goals were designed that would cover the main topics of the Differential Calculus UA. Each of the goals describes its scope, value and activities to be developed by the student.

\begin{tabular}{|c|c|}
\hline \multicolumn{2}{|c|}{ Diagnosis of algebraic, geometric and trigonometric skills } \\
\hline Goal & Activity \\
\hline $\begin{array}{l}\text { Goal 0: Diagnosis } \\
\text { Value of this goal } 0 \%\end{array}$ & $\begin{array}{l}\text { Carry out the Diagnosis on } \\
\text { algebraic, geometric and } \\
\text { trigonometric skills. No } \\
\text { later than February 26, } \\
2021 \text { at } 11: 59 \text { p.m. Use } \\
\text { only pencil, paper and } \\
\text { scientific calculator. }\end{array}$ \\
\hline \multicolumn{2}{|c|}{$\begin{array}{l}\text { Course: Functions and Derivatives } \\
\text { ce: Apply the concepts and procedures of calculus } \\
\text { rentiation of functions, through the use of limits } \\
\text { ation theorems, supported by information } \\
\text { s, to solve everyday problems, science and } \\
\text {, with a disposition for collaborative work, } \\
\text { honesty. }\end{array}$} \\
\hline \multicolumn{2}{|c|}{$\begin{array}{l}\text { Unit 1: Functions of a variable } \\
\text { Identify the various types of functions, through their different } \\
\text { representations (graphical, numerical and analytical), for use } \\
\text { in the derivation and modeling processes, with active, } \\
\text { analytical and proactive participation. }\end{array}$} \\
\hline Goal & Activity \\
\hline $\begin{array}{l}\text { Goal 1.1: Solve the different } \\
\text { types of inequalities through } \\
\text { the use of the appropriate } \\
\text { theorems. } \\
\text { Value of this goal } 2 \%\end{array}$ & $\begin{array}{l}\text { Read the support material. } \\
\text { Review the web pages. It is } \\
\text { suggested to prepare the } \\
\text { exercises proposed in this } \\
\text { goal and participate in the } \\
\text { survey no later than } \\
\text { February } 22,2021 \text { at } 11: 59 \\
\text { p.m. }\end{array}$ \\
\hline $\begin{array}{l}\text { Goal 1.2: Interpret the concept } \\
\text { of function and its different } \\
\text { representations, as well as its } \\
\text { classification. Value of this } \\
\text { goal 5\% }\end{array}$ & $\begin{array}{l}\text { Read the support material. } \\
\text { Review the web pages. It is } \\
\text { suggested to prepare the } \\
\text { exercises proposed in this } \\
\text { goal and participate in the } \\
\text { survey no later than } \\
\text { February } 22,2021 \text { at } 11: 59 \\
\text { p.m. }\end{array}$ \\
\hline
\end{tabular}

\begin{tabular}{|l|l|}
\hline $\begin{array}{l}\text { Goal 1.3: Identify the } \\
\text { algebraic functions, as well as } \\
\text { interpret the changes from the } \\
\text { modification of parameters, } \\
\text { displacements, stretching and } \\
\text { reflections. Value of this goal } \\
8 \%\end{array}$ & $\begin{array}{l}\text { Read the support material. } \\
\text { Review the web pages. It is } \\
\text { suggested to prepare the } \\
\text { exercises proposed in this } \\
\text { goal and participate in the } \\
\text { survey no later than } \\
\text { February 22, 2021 at 11:59 } \\
\text { p.m. }\end{array}$ \\
\hline $\begin{array}{l}\text { Goal 1.4: Obtain the } \\
\text { operations of addition, } \\
\text { subtraction, multiplication and } \\
\text { division between functions, as } \\
\text { well as the composition and } \\
\text { inverse of a function. Value of } \\
\text { this goal 6\% }\end{array}$ & $\begin{array}{l}\text { Read the support material. } \\
\text { suggested to prepare the } \\
\text { exercises proposed in this } \\
\text { goal and participate in the } \\
\text { survey no later than }\end{array}$ \\
\hline $\begin{array}{l}\text { Goal 1.5: Distinguish } \\
\text { characteristics of transcendent } \\
\text { functions such as their period, } \\
\text { domain, range, as well as their } \\
\text { representations. Value of this } \\
\text { goal 4\% }\end{array}$ & $\begin{array}{l}\text { Read the support material. } \\
\text { Review the web pages. It is } \\
\text { suggested to prepare the } \\
\text { exercises proposed in this } \\
\text { goal and participate in the }\end{array}$ \\
survey no later than \\
February 22, 2021 at 11:59 \\
p.m.
\end{tabular}

Table 2 General map of the course Source: Self-made

The goals set for each unit of the UA descriptive letter were described based on three questions. What do I need to have at my disposal? What steps should I take? and How will I know that I achieved the goal? Next, the description of goal 1.1 is shown in table 3 as an example, showing the sequence that each activity must take to achieve the objectives set.

\section{On platform (week 1)}

First. Review the following material that is available for this goal.

Goal 1.1 Solve the different types of inequalities through the use of the appropriate theorems.pdf

Second. Make a documentary search, in reliable sources where you can find more information on this topic. You can also consult the following link, to have a clearer idea of the resolution of inequalities.

Video-Linear inequalities

Video-Inequalities with absolute value

Third. It is suggested that you elaborate the proposed exercises.

Goal 1.1 Task-Solve the different types of inequalities through the use of the appropriate theorems.pdf

Bedroom. Participate in the survey, you find it as Goal 1.1 Survey-Inequalities

- Expiration / delivery dates:

- Goal 1.1 Survey-Inequalities no later than Monday, February 22, 2021 before 24:00.

- Learning reflection How will I know that I have achieved the goal?

- I know the classification of real numbers.

- I know the different types of intervals.

- I classify real numbers as rational or irrational.

- I solve linear and absolute value inequalities.

Evaluation criteria:

Survey-Inequalities (2\%).

Goal 1.1 is equivalent to $2 \%$ of your final grade for the Functions and Derivatives course.

Table 3 Goal 1.1 content

Source: Self-made

AGUILAR-SALINAS, Wendolyn Elizabeth \& DE LAS FUENTES-LARA, Maximiliano. A virtual learning environment for a remedial differential calculus course. Journal-Mathematical and Ouantitative Methods. 2021 


\section{Evaluation method}

The evaluation method was designed through surveys, which evaluated each of the goals of the course. To construct each survey, the Nitko (1994) model was adopted to develop curriculum-oriented exams. This model is complemented by the methodology for the construction of criterial tests of Popham (1990) and with methodological and operational contributions of Contreras $(1998,2000)$. The quality analysis of the measuring instrument is done according to the Classical Test Theory (TCT), so that the designed instrument allows to measure the abilities of the students in the developed subject.

A quality analysis of the instrument was developed through content and criteria validity. The validity of the content is guaranteed from the selection of appropriate indicators related to mathematical processes and the contrast of the validity of the reagents through the judgment of experts (Alsina and Coronata, 2014). In this type of validity, a panel of expert judges with at least 5 years of seniority in the subjects object of the validation is selected who must analyze the coherence of the items with what is to be evaluated, the complexity of the items and the ability cognitive to be evaluated (Barrazas, 2007) as well as the sufficiency and relevance of the reagents, considering the aspects of the construct that are relevant, included in the competencies and indicators (Cisneros, Jorquera and Aguilar, 2012).

Each survey designed aims to verify the knowledge or mastery of the students regarding the contents or topics of differential calculus that are considered necessary in engineering programs. In order to determine if the measurement instrument reagents truly examine the topics and indicators of achievement established in the design specifications, a review was carried out with a team of 5 judges, university professors from the area of mathematics with a master's degree or $\mathrm{PhD}$ and outside the process of design and construction of the measuring instrument.

The survey was designed based on clear specifications for each item, including: competence, indicator, content type, difficulty, instructions to answer the item, item base, distractors, correct answer, sample item, estimated execution time, and congruence with the competition.
Likewise, 30 items were built for each of the surveys, items aligned with the curriculum and multiple choice were built, from which the Blackboard platform randomly selects 10 items for each student.

The general indices considering the 15 surveys applied to the students are observed in Table 4, where it is evident that each item is well discriminated and that the difficulty ranges between $15 \%$ and $97 \%$ with an average of $69 \%$, which means that the makes it ideal to apply to large masses.

\begin{tabular}{|c|c|c|}
\hline & $\begin{array}{l}\text { Discrimination } \\
\text { index }\end{array}$ & $\begin{array}{l}\text { Difficulty } \\
\text { index }\end{array}$ \\
\hline Minimum & 0.15 & 0.15 \\
\hline Maximum & 0.78 & 0.97 \\
\hline Rank & 0.63 & 0.82 \\
\hline Half & 0.52 & 0.69 \\
\hline $\begin{array}{l}\text { Standard } \\
\text { deviation }\end{array}$ & 0.11 & 0.17 \\
\hline
\end{tabular}

Table 4 Percentages associated with the construction of the surveys

Source: Own elaboration

The surveys carried out are considered as a criterial test by virtue of the fact that it is intended to determine mathematical abilities and support the integral calculus course. The Difficulty Index (ID) is related to the proportion of students who correctly solve an item, and is calculated according to Crocker and Algina (1986). There are parameters for the acceptance of a reagent according to its level of difficulty, the one established by Contreras, Backhoff and Larrazolo (2004), says that it must be greater than 0.05 and less than 0.95 , for the TCT this index must be between 0.1 and 0.9. According to Backhoff, Larrazolo and Rosas (2000), the average level of difficulty of the instrument should range between 0.5 and 0.6 , distributing the values of the difficulty index as follows: $5 \%$ of highly easy items ( $0.87<\mathrm{ID}<1), 20 \%$ moderately easy $(0.74<\mathrm{ID}<0.86), 50 \%$ with a medium difficulty $(0.53<\mathrm{ID}<0.73), 20 \%$ moderately difficult $(0.33<\mathrm{ID}<0.52)$ and $5 \%$ highly difficult (ID $<0.32$ ). 
The discrimination index (IDC) of the item allows differentiating (discriminating) between students who obtained high scores in the test and those who obtained low scores, and is related to the high possibility of answering the item correctly those students with a general performance outstanding in the test, opposite situation in the case of students with a poor performance, in this analysis $54 \%$ of the sample population is considered, since $27 \%$ of the students with high performance and the same percentage of students are included with the lowest yield, for each reagent that is reviewed. For Contreras, Backhoff and Larrazolo (2004) and for TCT, the discriminative value of the reagent is considered appropriate if it is greater than 0.2. According to Guilford (1975), the discrimination index of a reagent is accepted if it yields a value greater than 0.2 or 0.3 . The IDC scale according to Backhoff, Larrazolo and Rosas (2000) is: bad (IDC <0.20), regular (0.20 $<$ IDC <0.30), good (0.30<IDC <0.40) and excellent (IDC>0.40).

\section{Final thoughts}

A remedial course was designed for the subject of Differential Calculus called "Functions and Derivatives" to support students who are taking the Integral Calculus UA, with the aim that each of the students who take it acquire the mathematical skills of Differential Calculus that allows you to successfully complete your time at the Comprehensive Calculus UA.

A team of judges evaluated whether the contents of the reagents inquired about the topics of the Differential Calculus UA proposed, if the reagents are indicators of what it is intended to measure, the judgments of the professionals were favorable in relation to the diagnostic possibilities of each one of the polls.

To calculate the reliability, two methods were used, KR-20 and split halves, the results are consistent between the first version and the last one, so the instrument is highly reliable and its use can be considered to be applied on a large scale.

The importance of this remedial course lies in the help it provides to the student in the possible learning lags of Differential Calculus that have always existed and that have increased after the COVID19 pandemic.

\section{References}

Agudelo, M. (2009). Importancia del diseño instruccional en ambientes virtuales de aprendizaje. En J. Sánchez (Ed.): Nuevas Ideas en Informática Educativa, 5, 118 - 127, Santiago de Chile.

Alsina, Á. y Coronata, C. (2014). Los procesos matemáticos en las prácticas docentes: diseño, construcción y validación de un instrumento de evaluación. Educación Matemática En La Infancia, 3(2), 23-36.

Avitia, P., Candolfi, N., Arellano, E. y Uriarte, I. (noviembre de 2014). Implementación de cursos de matemáticas para estudiantes de Ingeniería en modalidad semipresencial: la experiencia de CITEC Valle de las Palmas. Congreso Iberoamericano de Ciencia, Tecnología, Innovación y Educación. Buenos Aires, Argentina.

Backhoff, E., Larrazolo, N. y Rosas, M. (2000). Nivel de dificultad y poder de discriminación del examen de habilidades y conocimientos básicos (EXHCOBA). Revista Electrónica de Investigación Educativa, 2(1), 1-19.

Barrazas, A. (2007). La consulta a expertos como estrategia para la recolección de evidencias de validez basadas en contenido. Investigación Educativa Duranguense, 7, 5-13.

Betegón, L., Fossas, M., Martínez, E. y Ramos, M. (2012). Entornos virtuales como apoyo a la docencia universitaria presencial: utilidad de Moodle. Anuario Jurídico y Económico Escurialense, XLIII, 273-302.

Brioli, C. y Garcial, I. (2011). Referente teórico y metodológico para el diseño instruccional de entornos virtuales de enseñanza y aprendizaje (EVEA). Docencia universitaria, XII (2), 7199.

Bruner, J. S. (1969). Hacia una teoría de la instrucción. México: Uthea.

Chiappe, A. (2008). Diseño instruccional: oficio, fase y proceso. Educación y Educadores, 11(2), 229-239.

Coll, C. y Monereo, C. (2008). Psicología de la educación virtual. Madrid: Ediciones Morata, S. L.

AGUILAR-SALINAS, Wendolyn Elizabeth \& DE LAS FUENTES-LARA, Maximiliano. A virtual learning environment for a remedial differential calculus course. Journal-Mathematical and Ouantitative Methods. 2021 
Cisneros, E., Jorquera, M. y Aguilar, A. (2012). Validación de instrumentos de evaluación docente en el contexto de una universidad española. Voces y Silencios: Revista Latinoamericana de Educación, 3(1), 41-55.

Contreras, L. A. (1998). Metodología para desarrollar y validar un examen de español, de referencia criterial y referencia normativa orientado por el curriculum, para la educación primaria en México, en Tercer Foro Nacional de Evaluación Educativa. Memorias. Veracruz: CENEVAL.

Contreras, L. A. (2000). Desarrollo y pilotaje de un examen de español para la educación primaria en Baja California. Tesis. Recuperado de:

http://eduweb.ens.uabc.mx/egresados/index.htm 1 (Consultado el 16-09-2005).

Contreras, L., Backhoff, E. y Larrazolo, N. (2004). Educación, aprendizaje y cognición. Teoría en la práctica. México: Manual moderno.

Córica, J. L., Portalupi, C., Hernández, M. L. y Bruno, A. (2010). Fundamentos de diseño de materiales para educación a distancia. $1^{\text {a }}$ edición, Editorial Virtual Argentina, Mendoza, Argentina.

Crocker, L. y Algina, J. (1986). Introduction to Classical and Modern Test Theory. Florida: Holt, Rinehart and Winston.

Dillenbourg, P., Schneider, D. y Synteta, P. (2002). Virtual Learning Environments. Proccedings of the 3rd Hellenic Conference "Information \& Communication Technologies in Education", 3-18.

Escontrela, R. (2003). Bases para reconstruir el diseño instruccional en los sistemas de educación a distancia. Revista Docencia Universitaria, 1 (4), 25-48.

García, L. (2017). Educación a distancia y virtual: calidad, disrupción, aprendizajes adaptativo y móvil. RIED. Revista Iberoamericana de Educación a Distancia, 20(2), 9-25. doi: http://dx.doi.org/10.5944/ried.20.2.18737
Gil, M. C. (2004). Modelo de diseño instruccional para programas educativos a distancia. Perfiles educativos, 26 (104), 93-114.

Guàrdia, L. y Sangrà, A. (2005). Diseño instruccional y objetos de aprendizaje; hacia un modelo para el diseño de actividades de evaluación del aprendizaje on-line. RED. Revista de Educación a Distancia, 4, 1-14. Recuperado de: https://www.um.es/ead/red/M4/guardia17.pdf

Gutiérrez, M.A. (1997). Educación multimedia y nuevas tecnologías. Madrid: Ediciones de la Torre.

López, R. (2005). Deficiencias en matemáticas que afectan el aprendizaje del cálculo diferencial en estudiantes de Ingeniería de una universidad privada (Tesis de Maestría). Universidad Industrial de Santander, Bucaramanga.

López, A. E., Ledesma, R. y Escalera, S. (2009). Ambientes Virtuales de Aprendizaje. Instituto Técnico Profesional. México, 2009. Recuperado de: http://investigacion.ilce.edu.mx/panel_control/d oc/Rayon_Parra.pdf

Nitko, A. J. (1994). A Model for Developing Curriculum-Driven Criterion-Referenced and Norm-Referenced National Examinations for Certification and Selection of Students. Conferencia Internacional sobre Evaluación y Medición Educativas, de la Asociación para el Estudio de la Evaluación Educativa (ASSESA). Osuna, F. y Abarca, F. (2013). Los nuevos roles en entornos educativos extendidos en red. La experiencia de diseño de un entorno virtual de aprendizaje en educación superior. Revista de Docencia Universitaria, 11(2).

Pineda, G. (2008). Análisis de los factores que inciden en la reprobación en los alumnos de la carrera de Ingneiero Bioquímico de la Escuela Nacional de Ciencias Biológicas del Instituto Politécnico. Tesis de Maestría, Instituto Politécnico Nacional, enero 2008. Recuperado de:

https://tesis.ipn.mx/jspui/bitstream/123456789/ 4240/1/ANALISISFACTORES.pdf

Popham, J. (1990). Modern educational Measurement: a practitioner's perspective. Boston: Prentice Hall. 
Riego, M. A. (2013). Factores académicos que explican la reprobación en cálculo diferencial. Conciencia Tecnológica, 46, julio-diciembre, 29-35. Recuperado de: https://www.redalyc.org/pdf/944/94429298006. pdf

Ruiz, E. F., Carmona, E. A. y Montiel, A. S. (2016). Importancia del cálculo en el desarrollo académico del ingeniero. Pistas Educativas, 120, noviembre de 2016, 402-420.

Umaña, A. C. (2009). Consideraciones pedagógicas para el diseño instruccional constructivista. Innovaciones Educativas, 11(16), 1-18.

Vasquez, D. (2020). Ventajas, desventajas y ocho recomendaciones para la educación médica virtual en tiempos de COVID-19. Rev CES Medicina, Especial COVID-19, 14-27.

Zúñiga, L. (2007). El cálculo en carreras de ingeniería: un estudio cognitivo. Revista Latinoamericana de Investigación en Matemática Educativa, 10(1), 145-175. 